\title{
A first insight into genotype $\times$ diet interactions in European sea bass (Dicentrarchus labrax L. 1756) in the context of plant-based diet use
}

\author{
Richard Le Boucher ${ }^{1,2,3,{ }^{*}}$, Marc Vandeputte ${ }^{1,2}$, Mathilde Dupont-Nivet ${ }^{1}$, Edwige Quillet ${ }^{1}$, \\ David Mazurais ${ }^{4}$, Jean Robin ${ }^{4}$, Alain Vergnet ${ }^{2}$, Françoise Médale ${ }^{5}$, Sadasivam Kaushik ${ }^{5}$, \\ Béatrice Chatain
}

\footnotetext{
${ }^{1}$ INRA, UMR1313 Génétique Animale et Biologie Intégrative, Jouy-en-Josas, France

2 Ifremer, Chemin de Maguelone, Palavas-les-Flots, France

${ }^{3}$ AgroParisTech, UMR1313 Génétique Animale et Biologie Intégrative, Paris, France

${ }^{4}$ Ifremer, UMR 1067, Laboratoire de Nutrition, Aquaculture et Génomique, Equipe Nutrition des poissons marins, Plouzane, France

${ }^{5}$ INRA, UMR1067, Laboratoire de Nutrition, Aquaculture et Génomique, St Pée-sur-Nivelle, France
}

*: Corresponding author : Richard Le Boucher, email address : $\underline{\text { richard.le.boucher@ifremer.fr }}$

\begin{abstract}
:
This preliminary study assessed genotype $\times$ diet interaction in late growth of European sea bass (Dicentrarchus labrax) fed with either a fish meal (FM)- or a fish oil (FO)-based diet (M) or an all-plantbased (PB) diet. A total of 550 fish from 224 families were reared together and tagged. DNA was sampled and microsatellites were used to assign parentage. When fish weight was $192 \pm 54 \mathrm{~g}$, two tanks were fed with M (FM: 100\%; FO: 100\%) and two others with PB (FM: 0\% and FO: 0\%). Body weight (BW), fork length (FL) and fillet lipid content (CorrFat) were analysed with a linear model and with REML methodology. We observed no significant differences between groups, but a slightly lower $(P=0.03)$ daily growth coefficient in sea bass fed PB than in those fed M. Heritability estimates of BW differed significantly from zero (PB: $0.37 \pm 0.18$; M: $0.47 \pm 0.24$ ). Sire $\times$ diet interactions were significant and genetic correlations ranged between 0.51 and 0.87 , showing genotype $\times$ diet interaction for BW and CorrFat. For the first time, genetic parameters in the context of total replacement of marine fishery by-products were estimated in European sea bass, showing re-ranking of family performances with extremely contrasted diets.
\end{abstract}

Keywords : genotype by diet $\times$ environment interaction, European sea bass, plant diet, genetic correlation 


\section{Introduction}

Over the past decades, aquaculture has become the animal production with the highest annual growth rate (FAO. State of world aquaculture 2008) thus trying to meet the increasing demands for seafood supplies coming from economically viable, environmentally friendly and societally acceptable production systems.

To make the production system sustainable, one of the well-known targets in aquaculture is to reduce the reliance on feeds based on ingredients derived from wild fishery resources (Tacon \& Metian 2008). Replacement of fish meal (FM) by plant protein sources has hence been a target of many studies and recent works on European sea bass (Dicentrarchus labrax) concluded that anywhere from 50 to even $98 \%$ of fish meal-derived proteins can be replaced by using plant protein sources with similar growth when fish oil is used as the lipid source (Olivia-Teles \& Gonçalvez 2001; Kaushik, Coves, Gutto \& Blanc 2004; Messina, Tulli, Messina, Franchin \& Tibaldi 2005; Dias, Conceição, Ana Ramalho Ribeiro, Pedro Borges, Valente \& Maria Teresa Dinis 2009), although in some cases total replacement of fish meal by single plant protein sources has been shown to lead to depressed growth (Dias, Alvarez, Arzel, Corraze, Diez, Bautista \& Kaushik 2005).

Replacement of fish oil (FO) by vegetable oils (VO) has also been widely studied in European sea bass and replacement of $60 \%$ of $\mathrm{FO}$ has been shown to have no negative impact on survival, growth and health of fish (Richard, Mourente, Kaushik \& Corraze 2006a; Izquierdo, Obach, Arantzamendi, Montero, Robaina \& Rosenlund 2003; Figueiredo-Silva, Rocha, Dias, Silva, Rema, Gomes \& Valente 2005; Mourente, Dick, Bell \& Tocher 2005) whereas growth performances were reduced at higher levels of substitution (80\%) (Montero, Robaina, Caballero, Ginés \& Izquidero 2005), contrary to what has been observed in salmonids, where total replacement of FO by VOs has been shown to have no adverse consequences in terms of growth performance (Torstensen, Bell, Rosenlund, Henderson, Graff, Tocher, Lie. \& Sargent, 2005; Richard, Kaushik, Larroquet, Panserat \& Corraze, 2006b). This difference between salmonids and marine teleosts such as the European sea bass is possibly linked to putative differences in fatty acid bioconversion capacities between freshwater and marine finfish (Watanabe, 1982; Sargent, Tocher \& Bell 2002).

In the general context of reducing the dependence on marine-ingredients (FO and FM) for developing aquafeeds, genetic improvement of farmed fish appears as an interesting complementary target (Gatlin, Barrows, Brown, Dabrowski, Gaylord, Hardy, Herman, Hu, Krogdahl, Nelson, Overturf, Rust, Sealey, Skonberg, Souza, Stone, Wilson \& Wurtele, 2007) and recent studies on salmonids suggest the existence of genetic variability for utilization of plant-based diets (Palti, Silverstein, Wieman, Phillips, Barrows \& Parsons 2006; Pierce, Palti, Silverstein, Barrows, Hallerman \& Parsons 2008; Dupont-Nivet, Médale, Leonard, Le Guillou, Tiquet, Quillet \& Geurden 2009). Since, in general, selection programs targeting mainly on growth rate using mostly commercial feeds using hitherto conventional feed ingredients, studying genetic parameters including genotype by diet interactions when using plant-based diets is a major step forward to address two issues. 1) will the rankings of European sea bass families fed on marine feeds be conserved or not if increased proportions of plant ingredients are used in the feed? and 2) whether it is possible to specifically select fish for growth on plant-based diets, thus making it a more environmentally-sustainable genotype of interest to future aquaculture?

The existence of genotype by diet interactions has been studied in Rainbow trout Onchorynchus mykiss (Palti et al. 2006; Pierce et al. 2008; Dupont-Nivet et al. 2009) 
and European whitefish Coregonus lavaretus (Quinton, Kause, Ruohonen \& Koskela 2007a; Quinton, Kause, Koskela \& Ritola 2007b). Significant interactions only appeared in the studies of Pierce et al. (2008) and of Dupont-Nivet et al. (2009), which both had the highest replacement rate (37.2 \% and 0\% for fishoil (FO) and $93.75 \%$ and $100 \%$ for fishmeal (FM) respectively), while the other works performed only partial replacement (FO: $11.4 \%$, FM: $87 \%$ for early stage and 100\% later as in Palti et al. (2006) ; FO: 0 \%, FM: $73.3 \%$ in Quinton et al. (2007a)). For European sea bass, a leading aquaculture species in the Mediterranean, no such studies exist, but bear significance as this species is reported to show a very high fish in/fishout ratio (Naylor, Goldburg, Primavera, Kautsky, Beveridge, Malcolm, Clay, Folke, Lubchenco, Mooney \& Troell 2000). Besides, high genetic gains for growth are possible in this species (Vandeputte, Dupont-Nivet, Haffray, Chavanne, Cenadelli, Parati, Vidal, Vergnet, \& Chatain 2009) using conventional feeds rich in FM and FO.

The present work focused on weight, length and lipid content. Known as a valuable trait in this species, fat deposition is known to be affected by dietary carbohydrate levels as well as protein sources (Dias et al. 2005). Saillant, Dupont-Nivet, Sabourault, Haffray, Laureau, Vidal \& Chatain (2009) demonstrated that the quality of prediction of lipid content with Distell Fish Fat-Meter, previously used on rainbow trout (Douirin, Haffray, Vallet \& Fauconneau 1998; Quillet, Le Guillou, Aubin \& Fauconneau 2005; Quillet, Le Guillou, Aubin, Labbé, Fauconneau \& Médale 2007) was accurate enough to assess genetic parameters in sea bass, with a moderate heritability $(0.28 \pm 0.12)$ for this trait. We measured and followed this trait during our trial.

We focused on growth of juvenile sea bass, where feed consumption is the highest, and chose to compare a marine ingredients based diet with a totally plant based-diet, free of any marine ingredient (FO: 0\%, FM: $0 \%$ ), in order to exacerbate any possible differences. All families were mixed in tanks to avoid confusion of genetic and environmental effects and pedigrees were redrawn a posteriori with microsatellite markers. In this study based on a total replacement of marine products, diet effect, heritability and genotype-diet interactions are assessed and analysed.

\section{Materials and methods}

\subsection{Experimental design}

This study was conducted in the Ifremer aquaculture station (Palavas-les-flots, France) with wild-caught West Mediterranean European sea bass broodstock. A full factorial mating design was used to cross 8 dams and 41 sires in order to obtain 328 families. Sperm was collected as described in Fauvel, Suquet, Dreanno, Zonno \& Menu (1998). After hormonal induction of ovulation $\left(10 \mu \mathrm{g} \cdot \mathrm{kg}^{-1}\right.$ luteinizing releasing hormone, Sigma D-TRP6LHRH), females were manually stripped and same volume of eggs were collected, mixed and divided into 41 aliquots. Each aliquot of eggs was then fertilized with sperm of one single sire to avoid sperm competition, as described by Saillant, Chatain, Fostier \& Przybyla (2001). All fertilizations were carried out within a thirty minutes period and eggs were pooled in conical-bottom incubators. Floating (live) and sinking (dead) eggs were separated at 48 hours post fertilization $\left(14^{\circ} \mathrm{C}\right)$ by decanting at a salinity of $48 \%$ (Chatain 1994). Viable eggs $(50 \mathrm{ml})$ were transferred in a $0.5 \mathrm{~m}^{3}$ incubator (in triplicate) containing all families and hatched. Until day 68, larvae were kept in the same tank and the temperature rose from $14^{\circ} \mathrm{C}$ to $20^{\circ} \mathrm{C}$. Fish were fed Artemia for 40 days then weaned on artificial feed. 
At day 306 post fertilization (dpf), 2000 randomly chosen fish (mean weight: $48.5 \pm$ $16.0 \mathrm{~g}$, mean standard length: $13.9 \pm 1.4 \mathrm{~cm}$ ) were tagged using a Passive Integrated Transponder (AEG-Id, Germany) and individual fin clips were stored in $100 \%$ ethanol for DNA extraction, genotype analysis and parentage assignment. Until day 588, fish were used in a feed deprivation trial to assess heritability of weight loss as detailed in Grima, Vandeputte, Ruelle, Vergnet, Mambrini \& Chatain (2010). On day 588, 785 of them were then randomly sampled, distributed in four $5 \mathrm{~m}^{3}$ tanks (196 fish/tank) and fed with a commercial feed during 135 days to avoid potential effect of the previous study. Water temperature was $21^{\circ} \mathrm{C}$ on average, salinity $38 \%$ and the system was recirculated (10-30\% renewal/day). The feeding trial, described in this paper, started with fish aged of 588 days and weighed $192 \mathrm{~g} \pm 54 \mathrm{~g}$.

\subsection{Feeding trial and experimental diets}

Two tanks received a marine $(\mathrm{M})$ experimental diet containing fish meal and fish oil and the two others received a plant-based (PB) experimental diet devoid of fishmeal and fish oil. Both diets were manufactured using a twin-screw extruder (Clextral BC45, Clextral, France) at the INRA experimental facilities (Donzacq, France). Ingredients and proximate composition of diets are reported in the Table 1. Diet $\mathrm{M}$ contained a blend of fishmeal, corn gluten meal, wheat gluten and extruded wheat as protein sources whereas diet PB contained a blend of corn gluten meal, soybean meal, wheat gluten, extruded wheat and white lupin. In order to obtain a total replacement of fish products, only linseed oil (LO $9.4 \%$ ) was used in the PB diet whereas diet M contained fish oil (FO $8.5 \%$ ). Linseed oil is rich in 18:3 n-3 (50\% of total fatty acids) incorporation of which was thus intended to supply high levels of 18:3 n-3 but no long-chain n-3 polyunsaturated fatty acids such as the EPA or DHA in the PB diet and to verify the potential bioconversion capacities of 18 carbon fatty acids in this euryhaline species. The fatty acid composition of the two feeds is provided in Table 2. Diet PB also contained an attractant mix to increase the palatability (Table 1) which contained only non essential amino acids (alanine, glycine), a physiological amino acid (taurine) and betaine. The nitrogen contents of these were also taken into account in formulating the feeds to be comparable between the two feeds. Both diets were isoproteic (digestible protein: $43 \%$ of dry matter) isolipidic (fat: $13 \%$ of dry matter), and is energetic (17 $\mathrm{MJ} . \mathrm{kg}^{-1}$ ). Fish were fed one daily meal until apparent satiation (determined when uneaten pellets started to be collected in the fecal traps), and all uneaten pellets were counted. The meal duration was between $1 \mathrm{~h}$ and $1 \mathrm{~h} 30$ every day and the trial lasted 262 days.

\subsection{Data collection}

The feeding trial was divided in 6 periods flanked by 7 measures at 588, 605, 647, 679, $736,787,850 \mathrm{dpf}$ in order to get a measure approximately every 40 days. Fish weights and standard lengths were measured at each date and lipid content was indirectly measured with a Fish Fatmeter (FM692,Distell, Fauldhouse, UK) at same days using the SEABASS-1 calibration, (mean of four measurements, two on each side of the fish, in $\%$ fresh matter). Daily growth coefficient DGC60 $=\left(\mathrm{W}_{6}{ }^{1 / 3}-\mathrm{W}_{0}{ }^{1 / 3}\right) /\left(\mathrm{t}_{6}-\mathrm{t}_{0}\right)$ was also calculated (with $W_{6}$ the weight at the end of the period $6, W_{0}$ the weight at the end of the period $0, t_{6}-t_{0}$ the duration in days between dates).

\subsection{Parentage assignment}

Rapid DNA extractions were made from the fin clips, using Chelex resin as described in Estoup, Largiader, Perrot \& Chourrout (1996). Parents and offspring were assayed at 5 or 6 microsatellite loci as described in Chistiakov, Dimitry, Hellemans \& Volckaert (1996) and Garcia De Leon, Dallas, Chatain, Canonne, Versini \& Bonhomme (1995). 
Four loci were combined in two multiplex panels (multiplex 1: DLA0016 and DLA0014; multiplex 2: Labrax 8 and Labrax 17) while the locus Labrax 29 was assayed singly. Parentage was performed by exclusion using VITASSIGN (Vandeputte, Mauger \& Dupont-Nivet 2006). When more than one parent pair was found per individual, the locus Labrax 3 was used to discriminate the potential families. At the end of this process, $99.2 \%$ of the fish sampled (778 of 784) had been successfully and unambiguously assigned to their parents.

\subsection{Statistical analyses}

Traits followed at the end of each period were the body weight $(B W)$, the standard length (SL) and the mean muscle fat content assessment divided by the decimal logarithm of $B W$ of each period (CorrFat) as bigger sea bass are known to be fatter.

Fish were sexed by visual inspection of the gonads on slaughtered fish at the end of the experiment, as sex is known to have a highly significant effect on European sea bass growth. Due to data collection problems, sex could only be recorded on 554 individuals. Parentage analyses showed that some fish belonged to under-represented half-sib families. Offspring from half-sib families with less than 5 fish were not used for further statistical analyses, Finally 550 individuals from 7 dams and 32 sires were used (224 full-sib families).

Preliminary analyses indicated that the sire*dam effect was never significant for any trait and was therefore not included in the models. To determine the significance of fixed effects (sex, diet) and to evaluate the significance of genotype*diet interactions, data were first analysed using SAS-GLM (SAS Institute Inc., Cary, NC) with the following model:

$$
\mathrm{Y}_{\mathrm{ijklmn}_{\mathrm{j}}}=\mu+\text { Diet }_{\mathrm{i}}+\text { Sex }_{\mathrm{j}}+\operatorname{tank(diet)}{ }_{\mathrm{k}(\mathrm{i})}+\text { sire }_{1}+\text { dam }_{\mathrm{m}}+\text { sire*diet }_{\mathrm{il}}+\text { dam*diet }_{\mathrm{im}}+\mathrm{e}_{\mathrm{ijk}(\mathrm{i}) \operatorname{lmn}}
$$

Where $Y_{i j k l m n}$ is the performance of individual $n, \mu$ is the general mean, Diet $t_{i}$ is the fixed effect of the diet, Sex $x_{j}$ is the fixed effect of sex $j$ (1=male, $2=$ female), tank $k_{k(i)}$ is the random effect of the tank $k(k=1,2)$ nested within diet $i$, sire, is the random effect of sire $\mathrm{I}, \mathrm{dam}_{\mathrm{m}}$ is the random effect of dam $\mathrm{m}$, sire* diet $_{\mathrm{il}}$ the random interaction between sire I and diet $\mathrm{i}$, dam*diet ${ }_{i n}$ the random interaction between dam $n$ and diet $\mathrm{i}$ and $\mathrm{e}_{\mathrm{ijk} \mathrm{km}}$ is the random residual.

Genotype by diet interactions were also quantified through genetic correlations between the trait of interest with diet $M$ and the same trait with diet PB, considered as two different traits in the analysis. In this case, GxE (genetic by environment) interaction is the difference between 1 and the genetic correlation, and the closer to 1 the correlation, the smaller the GxE interaction. To estimate this correlation as well as trait heritability, the following model was used in ASREML (Gilmour, Gogel \& Cullis 2002) :

$$
\mathrm{Y}_{\mathrm{ijklm}}=\mu+\mathrm{Sex}_{i}+\text { Tank }_{j}+\text { sire }_{k}+\text { dam }_{\mathrm{l}}+\mathrm{e}_{\mathrm{ijklm}}
$$

Where $Y_{i j k l m}$ is the performance of individual $m, \mu$ is the general mean, Sex is the fixed effect of sex $\mathrm{j}$ (1=male, 2=female), Tank $\mathrm{k}_{\mathrm{j}}$ is the fixed effect of the tank $\mathrm{j}(\mathrm{j}=1,2$; two tanks per diet), sire ${ }_{k}$ the random effect of sire $k$, dam, the random effect of dam I and $\mathrm{e}_{\mathrm{ijk} k \mathrm{~m}}$ is the random residual. The sire component of variance $\left(\sigma^{2}\right)$ was used to estimate additive genetic variance $\left(\sigma_{A}^{2}\right)$ through the formula $\sigma_{A}^{2}=4 \sigma_{S}^{2}($ Becker 1984) and 
heritability was estimated as the ratio $h^{2}=\sigma_{A}^{2} / \sigma_{P}^{2}$ with $\sigma_{P}^{2}$ the estimate of phenotypic variance.

\section{Results}

\subsection{Diet effect}

After 9 months of the growth trial, total mortality was $0.3 \%(0.6 \%$ in $\mathrm{PB}, 0.0 \%$ in $\mathrm{M})$. Descriptive statistics of studied traits at the end of the study are given in Table 3. Linear model estimates of the mean weight show a 3.1 fold increment with the $\mathrm{M}$ diet and a 2.7 fold increment with the PB diet. BW of fish fed the PB diet was never significantly lower than fish fed diet $\mathrm{M}$ throughout the whole experimental period (Table 4). However, differences between diets increased from period $1(+11.1 \%)$ to period 6 $(+16.4 \%)$ where it became suggestive $(P<0.06$, see Figure 1$)$. No differences were observed between fish fed with the two diets for muscle lipid content (CorrFat, $\mathrm{P}>$ 0.51 , see Table 4). DGC calculated between the last (6) and the first (0) sampling dates was smaller in fish fed diet PB $(P<0.03)$.

\subsection{Linear model, heritability estimates and genetic correlations}

Diet effects or dam*diet effects were not significant on BW and CorrFat at any sampling point (Table 4). Sire*diet interactions on BW and CorrFat were significant, showing a significant re-ranking of the sire families between diets for these traits. The multiple measures and individual tagging enabled us to see an increase of significance of the sire*diet interaction during the trial.

Heritability estimates of body weight differed significantly from zero $( \pm 1.65$ S.E. for a $90 \%$ sure of rejecting null hypothesis) whether both diets are combined $\left(B W_{6}: 0.30 \pm\right.$ $0.13)$ or considered separately $\left(B W_{6}(\mathrm{~PB}): 0.37 \pm 0.18 ; B W_{6}(\mathrm{M}): 0.47 \pm 0.24\right)$ except for date 3 in PB batch (Table 5). The highest heritability estimates were obtained for CorrFat at measure $3(0.78 \pm 0.21)$ Two heritability values for CorrFat were over 1 , probably due to estimation problems resulting from the small size of the dataset. Heritability estimates were always higher with diet $\mathrm{M}$ and tended to decrease over time for both diets although no significant differences could be shown because of the high values of standard errors (Table 5).

Genetic correlations calculated using model (2) are shown in Table 5. They are all comprised between 0.51 and 0.99 , lower values suggesting existence of genotype by environment interactions. Between date 3 and 6 , the genetic correlation reduced from 0.81 to 0.51 for $B W$ and from 0.99 to 0.83 for CorrFat. Standard errors of estimated genetic correlations are too high to show significant difference between them and it does not allow to conclude that decreasing trend at the end of each period is significant (Fig. 1)

\section{Discussion}

The objectives of this preliminary study were to evaluate genotype by diet interactions in European sea bass in the case of total replacement of fish products in the diet, together with the estimation of heritabilities of body weight, length and fat content in both feeding contexts. 


\subsection{Diet effect}

A16.4\% difference in final weight between fish fed the marine $(M)$ diet and the fish fed plant-based (PB) diet was found after 262 days of trail, but it was not statistically significant. Kaushik et al. (2004) previously showed that almost total replacement of FM does not have any adverse effect on the growth of European sea bass. The present results clearly proved that it is possible to go further as FO and FM total replacement can lead to good performances in similar conditions. Since the feeds were extruded, the putative presence of anti-nutritional factors from plant protein sources were reduced, as also demonstrated by the more or less equivalent growth performance of the two groups. This lack of significant effects could also be due to the experimental design which was probably not optimal to detect feed effects (only two replicate tanks per feed, with significant tank effects for some dates), since the primary goal of this study was to detect genotype by feed interactions.

The recorded growth rate was lower than those reported in earlier studies (Dias, Corraze, Arzel, Alvarez, Bautista, Lopez-Bote \& Kaushik 1999; Kaushik et al. 2004). Smaller growth rate has also been reported with sea bass in the case of partial FM or FO replacement (Dias et al. 2005; Montero et al. 2005). DGC calculated on the whole period takes into account the initial weight of each individual and is higher in $\mathrm{M}$ batch, contrary to weight. The fact that PB fed fish took up to two weeks to feed normally after the initiation of the experiment, while $M$ fish ate normally after 2-3 days, supports the hypothesis of a low initial palatability of the PB diet and the need for a period of adaptation.

Estimates of muscle lipid contents did not show differences between fish from the two dietary groups which is consistent with results obtained in Atlantic salmon fed vegetable-oil based feeds (Nanton, Vegusdal, Anna Maria Bencze Rørå, Ruyter, Baeverfjord \& Torstensen 2007; Torstensen et al. 2005). Indeed, dietary lipid sources are known not to affect lipid deposition in either liver or muscle in sea bass, but inclusion of vegetable oils in fish diets modifies the body fatty acid profile (Izquidero et al. 2003).

To our knowledge, this is the first ever study with European sea bass fed with a complete marine ingredients-free diet. Even if a vegetable oils blend can mimic the fatty acid profile of fish oil for total saturated fatty acids (SFA), monounsaturated fatty acids (MUFA) and poly-unsaturated fatty acids (PUFA) (Torstensen et al. 2005; Francis, Turchini, Jones, De Silva \& Sena 2007), deficiency in n-3 long chain PUFA can still appear (Turchini, Bente, Torstensen \& Wing-Keong 2009). Moreover, it is generally recognised that marine fish have a lower ability to convert $18 \mathrm{C}$ fatty acids into longer polyunsaturated fatty acids (Watanabe 1982) and will exhibit direct requirements for HUFA (Sargent, Tocher \& Bell 2002). Previous works have reported the necessity of $1.0 \%$ of n-3 HUFA to fulfil essential fatty acid requirements in sea bass (review by Turchini et al. 2009). The total absence of such fatty acids in diet PB was probably partially compensated by fish reserves inherited from common feeding past, although the final body weight was almost thrice the initial body weight. Muscle fatty acid profiles on a subsample of the same fish have shown differences between the two dietary groups reflecting dietary fatty acid profiles but still maintaining non-negligible levels of the long chain w3 fatty acids (Geay, Santigosa, Corporeau, Boudry, Dreano, Corcos, Bodin, Vandeputte, Zambonino-Infante, Mazurais \& Cahu, in press). 


\subsection{Genetic parameters}

Sire*Diet interaction became significant for both traits (BW and CorrFat) during the growth trial, indicating that a general reranking of the sire families appeared in response to the diet challenge. A statistical procedure (GLM procedure in SAS) allowed us to check if one of the effects is significant inside each level of the other effect of the interaction. Known as simple effects (Winer 1971), it confirms that significance of diet effect on $B W$ exists for 10 of the 32 sire families $(P<0.05)$.

One interesting finding of the present study is the existence of sire $x$ diet interactions for both body weight and muscle lipid content measured with fatmeter in European sea bass in case of total replacement of marine products in the diet in a late growth context. In the whitefish, Quinton et al. (2007b) found only weak genotype-diet interaction for growth (genetic correlation for daily gain: $0.99 \pm 0.13$ ). Therefore, they predicted that changing from fish meal-based to soybean meal based diets should have only a minor influence on fish breeding programs. Palti et al. (2006) found no family $x$ diet interactions for growth in rainbow trout fed with fishmeal or gluten-based diet. In our experiment, total substitution leads to clear interactions for body weight and brings results close to the conclusions of Pierce et al. (2008) and Dupont-Nivet et al. (2009) in rainbow trout. Analysis of the evolution of sire*diet interaction shows that it became significant very soon in the trial (after 17 days) for BW and much later for CorrFat (after 199 days). Same pattern of changes is observed with genetic correlation (after 91 days for BW and 148 days for CorrFat) showing that both calculations are consistent. Considering that weight measurement are accurate on fish of such size, increase of interaction with time could be due to the amplification in differences between families who differ in genetic values (Saillant, Dupont-Nivet, Haffray \& Chatain 2006). This would indicate that variability appears fast and remains or increases under these conditions.

Estimates of body weight heritability when $\mathrm{M}$ and PB diets are combined were almost all significantly higher than 0 , but lower than or equal to those previously found European in sea bass: 0.60 for logarithm of body weight (Saillant et al. 2006)); 0.340.46 (Dupont-Nivet, Vandeputte, Vergnet, Merdy, Haffray, Chavanne \& Chatain 2008); 0.63 (Saillant et al. 2009); 0.34-0.60 (Vandeputte et al. 2009). Notwithstanding the moderate sample size of the present study, heritability estimates can be considered moderate to high for body weight and confirm that European sea bass is a good candidate for selection on these traits (Dupont-Nivet et al. 2008; Vandeputte et al. 2009). The main conclusion is that sea bass fed on PB diet are also good candidates for selection and that heritability estimates are not significantly different between diets.

High heritabilities of CorrFat confirm that rapid genetic gain is also possible for this quality trait, as already shown on rainbow trout (Quillet et al. 2005), common carp (Kocour, Mauger, Rodina, Gela, Linhart \& Vandeputte 2007) European sea bass (Haffray, Pincent, Dupont-Nivet, Vandeputte, Merdy, Chavanne \& Chatain 2007) and European whitefish (Kause, Quinton, Ruohonen \& Koskela 2009). Selection can be efficient on this trait whatever the diet (M or PB). Fat content of the muscle is a valuable trait for industry but impact of selection on the fatty acid profiles should also be studied in the context of lesser availability or increasing cost of fish oil. Further studies are warranted to check if the fatty acid profiles can present a genetic variability. The source of global ability to grow better on diets less dependent on wild marine fishery resources could be diverse: a better HUFA conversion, a better endurance of HUFA restriction or a better appetence to plant-based diets. We should add that this ability can express itself to a smaller extent possibly even with less extreme feeds. 


\section{Conclusion}

Our results let us expect that total replacement of marine products in late growth of European sea bass could be done with moderate effect on body weight and lipid content. Significance of genotype $x$ diet interaction in linear model and moderate genetic correlations between dietary groups for body weight and muscle fat content estimated by Fish Fatmeter correspond to a big step towards the consideration of feed products origin in the future fish selection. In this trial, we demonstrate that the performance ranking of the families for these traits is not similar with both diets. Extreme contrasts in diet composition as used here are not likely to be encountered in the industry today and lower interaction may then be observed with commercial diets. However, these diets were chosen to give rise to an increased genotype $x$ diet interaction. The existence of such interactions and of the high genetic variability on diet PB suggests it is possible to identify fish with a global ability to grow better on the future feeds.

This study proves that genetic improvement can be impacted by extreme changes in diet and the use of plant-based products. Still, this has to be confirmed in larger experiments, over a longer time period.

\section{References}

Alvarez M.J., Lopez-Bote C.J., Diez A., Corraze G., Arzel J., Dias J., Kaushik S.J. \& Bautista J.M. (1999) The partial substitution of digestible protein with gelatinized starch as an energy source reduces susceptibility to lipid oxidation in rainbow trout (Oncorhynchus mykiss) and sea bass (Dicentrarchus labrax) muscle. Journal of Animal Science 77, 3322-3329.

Becker W.A., 1984, Manual of quantitative genetics. Academic Enterprises, Pullman, Washington.

Blanc J.M. (2002) Interaction between diet and genetic aptitude for weight and growth in juvenile rainbow trout, Oncorhynchus mykiss (Walbaum). Aquaculture Research 33, 563-568.

Chatain B. (1994) Abnormal swimbladder development and lordosis in sea bass (Dicentrarchus labrax) and sea bream (Sparus auratus). Aquaculture 119, 371-379.

Chistiakov D.A., Hellemans B. \& Volckaert F.A.M. (2006) Microsatellites and their genomic distribution, evolution, function and applications: A review with special reference to fish genetics. Aquaculture 255, 1-29.

Dias J., Corraze G., Arzel J., Alvarez M.J., Bautista J.M., Lopez-Bote C. \& Kaushik S.J. (1999) Effets du rapport protéine/énergie des régimes alimentaires chez la truite et le bar en élevage. Perspectives de contrôle nutritionnel des dépôts lipidiques. Cybium 23 suppl.: 127-137.

Dias J., Alvarez M.J., Arzel J., Corraze G., Diez A., Bautista J.M. \& Kaushik S.J. (2005) Dietary protein source affects lipid metabolism in the European seabass (Dicentrarchus labrax). Comparative Biochemistry and Physiology A-Molecular \& Integrative Physiology 142, 19-31. 
Dias J., Conceiçao L.E.C., Ribeiro A.R., Borges P., Valente L.M.P. \& Dinis M.T. (2009) Practical diet with low fish-derived protein is able to sustain growth performance in gilthead seabream (Sparus aurata) during the grow-out phase. Aquaculture 293, 255262.

Douirin C., Haffray P., Vallet J.L. \& Fauconneau B. (1998) Determination of the lipid content of rainbow trout (Oncorhynchus mykiss) filets with the torry fish fat meter (R). Sciences des Aliments 18, 527-535.

Dupont-Nivet M., Vandeputte M., Haffray P. \& Chevassus B. (2006) Effect of different mating designs on inbreeding, genetic variance and response to selection when applying individual selection in fish breeding programs. Aquaculture 252, 161-170.

Dupont-Nivet M., Vandeputte M., Vergnet A., Merdy O., Haffray P., Chavanne H. \& Chatain B. (2008) Heritabilities and GxE interactions for growth in the European sea bass (Dicentrarchus labrax L.) using a marker-based pedigree. Aquaculture 275, 8187.

Dupont-Nivet M., Médale F., Leonard J., Le Guillou S., Tiquet F., Quillet E. \& Geurden I. (2009) Evidence of genotype-diet interactions in the response of rainbow trout (Oncorhynchus mykiss) clones to a diet with or without fishmeal at early growth. Aquaculture 295, 15-21.

Estoup A., Largiader C., Perrot E. \& Chourrout D. (1996) Rapid one tube DNA extraction for reliable PCR detection of fish polymorphic markers and transgenes. $\mathrm{Mol}$ Mar Biol Biotech 5, 295-298.

Food and Agriculture Organization. (2008) The State of World Fisheries and Aquaculture 2008. FAO, Rome, Italy. pp.24

Fauvel C., Suquet M., Dreanno C., Zonno V. \& Menu B. (1998) Cryopreservation of sea bass (Dicentrarchus labrax) spermatozoa in experimental and production simulating conditions. Aquatic Living Resources 11, 387-394.

Figueiredo-Silva A., Rocha E., Dias J., Silva P., Rema P., Gomes E. \& Valente L.M.P. (2005) Partial replacement of fish oil by soybean oil on lipid distribution and liver histology in European sea bass (Dicentrarchus labrax) and rainbow trout (Oncorhynchus mykiss) juveniles. Aquaculture Nutrition 11, 147-155.

Francis D.S., Turchini G.M., Jones P.L. \& De Silva S.S. (2007) Dietary lipid source modulates in vivo fatty acid metabolism in the freshwater fish, murray cod (Maccullochella peelii peelii). Journal of Agricultural and Food Chemistry 55, 15821591.

García de León F.J., Dallas J.F., Chatain B., Canonne M., Versini J.J., Bonhomme F. (1995) Development and use of microsatellite markers in sea bass, Dicentrarchus labrax (Linnaeus, 1758) (Perciformes: Serrandidae). Mol Mar Biol Biotech 4, 62-68.

Gatlin D.M., Barrows F.T., Brown P., Dabrowski K., Gaylord T.G., Hardy R.W., Herman E., Hu G.S., Krogdahl A., Nelson R., Overturf K., Rust M., Sealey W., Skonberg D., Souza E.J., Stone D., Wilson R. \& Wurtele E. (2007) Expanding the utilization of sustainable plant products in aquafeeds: a review. Aquaculture Research 38, 551-579. 
Geay F., Santigosa I Culi E., Corporeau C, Boudry P., Dreano Y., Corcos L., Bodin N., Vandeputte M., Zambonino-Infante J., Mazurais D. \& Cahu C. Regulation of FADS2 expression and activity in European sea bass (Dicentrarchus labrax, L.) fed a vegetable diet. Comparative Biochemistry and Physiology Part B: Biochemistry and Molecular Biology. In press, Accepted Manuscript

Gilmour A.R., Gogel B.J., Cullis B.R. et al. (2002) User Guide Release 1.0.

Grima L., Chatain B., Ruelle F., Vergnet A., Launay A., Mambrini M. \& Vandeputte M. (2010) In search for indirect criteria to improve feed utilization efficiency in sea bass (Dicentrarchus labrax). Part II: Heritability of weight loss during feed deprivation and weight gain during re-feeding periods. Aquaculture In Press, Accepted Manuscript.

Guillaume J., Kaushik S., Bergot P. \& Métailler R. (2001) Nutrition and feeding of fish and crustacea. Springer-Praxis Publishing, Chichester UK, 408p.

Haffray P., Pincent C., Dupont-Nivet M., Vandeputte M., Merdy O., Chavanne H. \& Chatain B. (2007) Heritabilities and GxE interactions for quality traits in the European sea bass (Dicentrarchus labrax L.). Aquaculture 272, S265.

Izquierdo M.S., Obach A., Arantzamendi L., Montero D., Robaina L. \& Rosenlund G. (2003) Dietary lipid sources for seabream and seabass: growth performance, tissue composition and flesh quality. Aquaculture Nutrition 9, 397-407.

Kause A., Quinton C.D., Ruohonen K. \& Koskela J. (2009) Genetic potential for the regulation of variability in body lipid and protein content of European whitefish (Coregonus lavaretus) British Journal of Nutrition 101 (10), 1444-1451.

Kaushik S.J., Covès D., Dutto G. \& Blanc D. (2004) Almost total replacement of fish meal by plant protein sources in the diet of a marine teleost, the European seabass, Dicentrarchus labrax. Aquaculture 230, 391-404.

Kocour M., Mauger S., Rodina M., Gela D., Linhart O. \& Vandeputte M. (2007) Heritability estimates for processing and quality traits in common carp (Cyprinus carpio L.) using a molecular pedigree. Aquaculture 270, 43-50.

Messina M., Tulli F., Messina C., Franchin C. \& Tibaldi E. (2005) Partial substitution of fish meal with vegetable protein sources in a diet for sea bass: Effects on lipogenesis. Veterinary Research Communications 29, 371-374.

Montero D., Robaina L., Caballero M.J., Ginés R. \& Izquierdo M.S. (2005) Growth, feed utilization and flesh quality of European sea bass (Dicentrarchus labrax) fed diets containing vegetable oils: A time-course study on the effect of a re-feeding period with a 100\% fish oil diet. Aquaculture 248, 121-134.

Mourente G., Dick J.R., Bell J.G. \& Tocher D.R. (2005) Effect of partial substitution of dietary fish oil by vegetable oils on desaturation and [beta]-oxidation of [1-14C]18:3n-3 (LNA) and [1-14C]20:5n-3 (EPA) in hepatocytes and enterocytes of European sea bass (Dicentrarchus labrax L.). Aquaculture 248, 173-186.

Nanton D.A., Vegusdal A., Rørå A.M.B., Ruyter B., Baeverfjord G. \& Torstensen B.E. (2007) Muscle lipid storage pattern, composition, and adipocyte distribution in different parts of Atlantic salmon (Salmo salar) fed fish oil and vegetable oil. Aquaculture 265, 230-243. 
Naylor R.L., Goldburg R.J., Primavera J.H., Kautsky N., Beveridge M.C.M., Clay J., Folke C., Lubchenco J., Mooney H. \& Troell M. (2000) Effect of aquaculture on world fish supplies. Nature 405, 1017-1024.

Oliva-Teles, A. \& Gonçalves, P. (2001) Partial replacement of fishmeal by brewers yeast (Saccaromyces cerevisae) in diets for sea bass (Dicentrarchus labrax) juveniles. Aquaculture 202, 269-278.

Palti Y., Silverstein J.T., Wieman H., Phillips J.G., Barrows F.T. \& Parsons J.E. (2006) Evaluation of family growth response to fishmeal and gluten-based diets in rainbow trout (Oncorhynchus mykiss). Aquaculture 255, 548-556.

Pierce L.R., Palti Y., Silverstein J.T., Barrows F.T., Hallerman E.M. \& Parsons J.E. (2008) Family growth response to fishmeal and plant-based diets shows genotype $x$ diet interaction in rainbow trout (Oncorhynchus mykiss). Aquaculture 278, 37-42.

Quillet E., Le Guillou S., Aubin J. \& Fauconneau B. (2005) Two-way selection for muscle lipid content in pan-size rainbow trout (Oncorhynchus mykiss). Aquaculture 245, 49-61.

Quillet E., Le Guillou S., Aubin J., Labbé L., Fauconneau B. \& Médale F. (2007) Response of a lean muscle and a fat muscle rainbow trout (Oncorhynchus mykiss) line on growth, nutrient utilization, body composition and carcass traits when fed two different diets. Aquaculture 269, 220-231.

Quinton C.D., Kause A., Ruohonen K. \& Koskela J. (2007a) Genetic relationships of body composition and feed utilization traits in European whitefish (Coregonus lavaretus L.) and implications for selective breeding in fishmeal- and soybean meal-based diet environments. Journal of Animal Science 85, 3198-3208.

Quinton C.D., Kause A., Koskela J. \& Ritola O. (2007b) Breeding salmonids for feed efficiency in current fishmeal and future plant-based diet environments. Genetics selection evolution 39 , 431-446.

Richard N., Kaushik S., Larroquet L., Panserat S \&, Corraze G. (2006b). Replacing dietary fish oil by vegetable oils has little effect on lipogenesis, lipid transport and tissue lipid uptake in rainbow trout (Oncorhynchus mykiss). British Journal of Nutrition 96,299309.

Richard N., Mourente G., Kaushik S. \& Corraze G. (2006a) Replacement of a large portion of fish oil by vegetable oils does not affect lipogenesis, lipid transport and tissue lipid uptake in European seabass (Dicentrarchus labrax L.). Aquaculture 261, 10771087.

Saillant E., Chatain B., Fostier A., Przybyla C. \& Fauvel C. (2001) Parental influence on early development in the European sea bass. Journal of Fish Biology 58, 1585-1600.

Saillant E., Dupont-Nivet M., Haffray P. \& Chatain B. (2006) Estimates of heritability and genotype-environment interactions for body weight in sea bass (Dicentrarchus labrax L.) raised under communal rearing conditions. Aquaculture 254, 139-147.

Saillant E., Dupont-Nivet M., Sabourault M., Haffray P., Laureau S., Vidal M.O. \& Chatain B. (2009) Genetic variation for carcass quality traits in cultured sea bass (Dicentrarchus labrax). Aquatic Living Resources 22, 105-112. 
Santigosa E., Sanchez J., Medale F., Kaushik S., Perez-Sanchez J. \& Gallardo M.A. (2008) Modifications of digestive enzymes in trout (Oncorhynchus mykiss) and sea bream (Sparus aurata) in response to dietary fish meal replacement by plant protein sources. Aquaculture 282, 68-74.

Tacon A.G.J. \& Metian M. (2008) Global overview on the use of fish meal and fish oil in industrially compounded aquafeeds: Trends and future prospects. Aquaculture 285, 146-158.

Torstensen B., Øyvind L. \& Frøyland L. (2000) Lipid metabolism and tissue composition in Atlantic salmon (Salmo salar L.)-Effects of capelin oil, palm oil, and oleic acid-enriched sunflower oil as dietary lipid sources. Lipids 35, 653-664.

Torstensen B.E., Bell J.G., Rosenlund G., Henderson R.J., Graff I.E., Tocher D.R., Lie O. \& Sargent J.R. (2005) Tailoring of Atlantic salmon (Salmo salar L.) flesh lipid composition and sensory quality by replacing fish oil with a vegetable oil blend. Journal of Agricultural and Food Chemistry 53, 10166-10178.

TurchiniG. M., Bente E., Torstensen B.E. \& Ng WW-K. (2009) Fish oil replacement in finfish nutrition. Reviews in Aquaculture 1, 10-57.

Vandeputte M., Peignon E., Vallod D., Haffray P., Komen J. \& Chevassus B. (2002) Comparison of growth performances of three French strains of common carp (Cyprinus carpio) using hemi-isogenic scaly carp as internal control. Aquaculture 205, 19-36.

Vandeputte M., Mauger S. \& Dupont-Nivet M. (2006) An evaluation of allowing for mismatches as a way to manage genotyping errors in parentage assignment by exclusion. Molecular Ecology Notes 6, 265-267.

Vandeputte M., Dupont-Nivet M., Haffray P., Chavanne H., Cenadelli S., Parati K., Vidal M.O., Vergnet A. \& Chatain B. (2009) Response to domestication and selection for growth in the European sea bass (Dicentrarchus labrax) in separate and mixed tanks. Aquaculture 286, 20-27.

Watanabe T. (1982) Lipid nutrition in fish. Comparative biochemistry and physiology B 73: 3-15.

Winer B. J. (1971) Statistical Principles in Experimental Design, Second Edition, New York: McGraw-Hill Book Co. 


\section{Tables}

Table 1 : Ingredients and proximal composition of the experimental diets (M: fishmeal and fish oil diet, PB : all fishmeal and fish oil replaced by plant products)

\begin{tabular}{lll}
\hline Diets & M & PB \\
\hline Ingredients $\left(\mathrm{g}^{-k^{-1}}\right)$ & 380 & 0 \\
Fishmeal & 180 & 200 \\
Corn gluten meal & 0 & 182 \\
Soybean meal & 72 & 20 \\
Wheat gluten & 253 & 72 \\
Extruded wheat & 0 & 140 \\
White lupin & 85 & 0 \\
Fish oil & 0 & 94 \\
Linseed oil & 0 & 10 \\
Soy lecithin & 0 & 27 \\
L-Lysine & 0 & 30 \\
CaHPO4.2H20 & 10 & 10 \\
Binder (Sodium alginate) & 0 & 15 \\
Attractant Mix* & 10 & 10 \\
Min. Premix $\dagger$ & 10 & 10 \\
Vit. Premix $\dagger$ & & \\
& & \\
Chemicals composition & 88.9 & 94.5 \\
Dry matter,(DM), \% & 49.4 & 49.6 \\
Crude protein, \% DM & 14.4 & 14.1 \\
Crude fat, \% DM & 7.0 & 6.1 \\
Ash, \% DM & 18.1 & 24.7 \\
Nitrogen free extract (NFE) $\ddagger$ \%DM & & \\
\hline
\end{tabular}

*Attractant mix contained (g/kg feed) taurine (3), betaine (3), glycine (2), alanine (2) and glucosamine (5) †As in Guillaume et al. (2001).

$\ddagger N F E=$ Dry matter-Crude protein-crude fat-Ash 
Table 2 : Fatty acid composition (\% of total fatty acids) of the two diets used for growing European sea bass (M: fishmeal and fish oil diet, PB : all fishmeal and fish oil replaced by plant products)

\begin{tabular}{|c|c|c|}
\hline Fatty acid & M & PB \\
\hline $8: 0$ & 0.02 & 0.02 \\
\hline $10: 0$ & 0.68 & 0.81 \\
\hline $12: 0$ & 0.08 & 0.01 \\
\hline 14:0 & 7.01 & 0.09 \\
\hline 15:0 & 0.70 & 0.04 \\
\hline $16: 0$ & 19.26 & 8.19 \\
\hline $17: 0$ & 0.46 & 0.11 \\
\hline $18: 0$ & 3.07 & 3.07 \\
\hline $20: 0$ & 0.16 & 0.21 \\
\hline $14: 1$ & 0.07 & - \\
\hline $16: 1$ & 5.79 & 0.16 \\
\hline $17: 1$ & 0.03 & 0.04 \\
\hline $18: 1$ & 15.70 & 21.72 \\
\hline $20: 1$ & 5.74 & 0.59 \\
\hline $22: 1$ & 4.53 & 0.21 \\
\hline $16: 2 n-4$ & 1.09 & - \\
\hline $16: 3 n-4$ & 0.85 & - \\
\hline $16: 4 n-1$ & 1.26 & - \\
\hline $18: 2 n-6$ & 7.51 & 21.97 \\
\hline $18: 3 n-6$ & 0.19 & - \\
\hline $20: 2 n-6$ & 0.20 & 0.04 \\
\hline $20: 3 n-6$ & 0.06 & - \\
\hline $20: 4 n-6$ & 0.47 & - \\
\hline $22: 2 n-6$ & 0.15 & 0.10 \\
\hline $18: 3 n-3$ & 0.99 & 41.31 \\
\hline $18: 4 n-3$ & 1.43 & 0.01 \\
\hline $20: 3 n-3$ & 0.11 & - \\
\hline $20: 4 n-3$ & 0.58 & - \\
\hline $20: 5$ n-3 (EPA) & 7.41 & - \\
\hline $21: 5 n-3$ & 0.27 & - \\
\hline $22: 5 n-3$ & 1.29 & - \\
\hline 22:6 n-3 (DHA) & 8.78 & - \\
\hline Sum saturates & 31.43 & 12.54 \\
\hline Sum monoenes & 31.85 & 22.72 \\
\hline Sum n-6 fatty acids & 8.58 & 22.11 \\
\hline Sum n-3 fatty acids & 20.85 & 41.33 \\
\hline Sum fatty acids & 96.14 & 98.79 \\
\hline
\end{tabular}


Table 3 : Effect of total replacement of fish oil and fish meal (M) by plant products (PB) on body weight $(B W)$, fork length $(F L)$, estimates of lipid content divided by the weight (CorrFat) and Daily Growth Coefficient $\left(\mathrm{DGC}=\mathrm{FBW}^{1 / 3}-\mathrm{IBW}^{1 / 3}\right) /$ duration with IBW = Initial body weight $(\mathrm{g})$ and $\mathrm{FBW}=$ final body weight $(\mathrm{g})$ ).

\begin{tabular}{lcccc} 
Traits & $\mathbf{M}$ & PB & F & P-value \\
\hline$B W(g)$ & $647.1 \pm 10.8$ & $556.1 \pm 10.7$ & 14.34 & 0.06 \\
FL $(\mathrm{mm})$ & $313.9 \pm 1.9$ & $299 \pm 1.9$ & 5.19 & 0.15 \\
CorrFat & $3.1 \pm 0.06$ & $3.1 \pm 0.06$ & 0.02 & 0.89 \\
DGC & $1.08 \pm 0.01$ & $0.92 \pm 0.01$ & 31.71 & 0.03
\end{tabular}

Table 4 : P-values for Diet, Tank(Diet), Sex, and interactions Sire*Diet and Dam*Diet effects for body weight (BW) and estimates of lipid content divided by the weight (CorrFat) for each date. In column 1, the ages of fish (in dpf) are indicated within brackets before the sampling time.

\section{Diet Tank(diet) Sex Dam*Diet Sire*Diet}

\begin{tabular}{ccccccc}
$\boldsymbol{B W}$ & \multicolumn{7}{l}{} \\
\hline$(588)$ & $\mathbf{0}$ & 0.57 & 0.47 & $<0.0001$ & 0.17 & 0.15 \\
$(605)$ & $\mathbf{1}$ & 0.31 & 0.01 & $<0.0001$ & 0.14 & 0.05 \\
$(647)$ & $\mathbf{2}$ & 0.31 & $<0.0001$ & $<0.0001$ & 0.30 & $<0.01$ \\
$(679)$ & $\mathbf{3}$ & 0.25 & $<0.0001$ & $<0.0001$ & 0.35 & $<0.01$ \\
$(736)$ & $\mathbf{4}$ & 0.20 & $<0.0001$ & $<0.0001$ & 0.30 & $<0.01$ \\
$(787)$ & $\mathbf{5}$ & 0.14 & $<0.01$ & $<0.0001$ & 0.21 & $<0.01$ \\
$(850)$ & $\mathbf{6}$ & 0.06 & 0.08 & $<0.0001$ & 0.16 & 0.01
\end{tabular}

CorrFat

\begin{tabular}{llccccc}
\hline$(588)$ & $\mathbf{0}$ & 0.65 & 0.08 & $<0.0001$ & 0.15 & 0.88 \\
$(605)$ & $\mathbf{1}$ & 0.84 & $<0.01$ & 0.22 & 0.34 & 0.64 \\
$(647)$ & $\mathbf{2}$ & 0.65 & 0.1 & $<0.0001$ & 0.83 & 0.66 \\
$(679)$ & $\mathbf{3}$ & 0.63 & $<0.01$ & $<0.0001$ & 0.99 & 0.29 \\
$(736)$ & $\mathbf{4}$ & 0.59 & 0.24 & $<0.0001$ & 0.99 & 0.05 \\
$(787)$ & $\mathbf{5}$ & 0.51 & $<0.0001$ & $<0.0001$ & 0.97 & 0.01 \\
$(850)$ & $\mathbf{6}$ & 0.89 & $<0.0001$ & $<0.0001$ & 0.96 & $<0.01$
\end{tabular}


Table 5: Genetic correlations between diets and heritability ( \pm standard errors) for Plant Based, Marine and both diets. Ages of the fish are indicated before the period number.

Genetic correlation $\quad h^{2}(\mathbf{P B})( \pm$ SE $) \quad h^{2}(\mathbf{M})( \pm$ SE $) \quad h^{2}$ (total) $( \pm$ SE)

\begin{tabular}{cccccc}
$\boldsymbol{B W}$ & & & & & \\
\hline$(588)$ & $\mathbf{0}$ & $\mathbf{0 . 9 9} \pm 0.00$ & $\mathbf{0 . 2 5} \pm 0.03$ & $\mathbf{0 . 4 4} \pm 0.04$ & $\mathbf{0 . 3 4} \pm 0.14$ \\
$(605)$ & $\mathbf{1}$ & $\mathbf{0 . 9 9} \pm 0.00$ & $\mathbf{0 . 0 7} \pm 0.00$ & $\mathbf{0 . 5 2} \pm 0.04$ & $\mathbf{0 . 3 1} \pm 0.13$ \\
$(647)$ & $\mathbf{2}$ & $\mathbf{0 . 9 9} \pm 0.00$ & $\mathbf{0 . 1 4} \pm 0.00$ & $\mathbf{0 . 5 2} \pm 0.04$ & $\mathbf{0 . 3 2} \pm 0.13$ \\
$(679)$ & $\mathbf{3}$ & $\mathbf{0 . 8 1} \pm 0.38$ & $\mathbf{0 . 2 1} \pm 0.16$ & $\mathbf{0 . 5 4} \pm 0.24$ & $\mathbf{0 . 3 1} \pm 0.13$ \\
$(736)$ & $\mathbf{4}$ & $\mathbf{0 . 6 4} \pm 0.35$ & $\mathbf{0 . 2 9} \pm 0.17$ & $\mathbf{0 . 5 1} \pm 0.24$ & $\mathbf{0 . 3 1} \pm 0.13$ \\
$(787)$ & $\mathbf{5}$ & $\mathbf{0 . 5 1} \pm 0.34$ & $\mathbf{0 . 3 6} \pm 0.18$ & $\mathbf{0 . 4 8} \pm 0.24$ & $\mathbf{0 . 3 0} \pm 0.13$ \\
$(850)$ & $\mathbf{6}$ & $\mathbf{0 . 5 1} \pm 0.34$ & $\mathbf{0 . 3 6} \pm 0.18$ & $\mathbf{0 . 4 7} \pm 0.24$ & $\mathbf{0 . 3 0} \pm 0.13$
\end{tabular}

\section{CorrFat}

\begin{tabular}{cccccc}
\hline$(588)$ & $\mathbf{0}$ & $\mathbf{0 . 9 9} \pm 0.00$ & $\mathbf{0 . 4 6} \pm 0.1$ & $\mathbf{0 . 6 0} \pm 0.08$ & $\mathbf{0 . 6 3} \pm 0.19$ \\
$(605)$ & $\mathbf{1}$ & n.e. & n.e. & n.e. & $\mathbf{0 . 6 3} \pm 0.19$ \\
$(647)$ & $\mathbf{2}$ & $\mathbf{0 . 9 9} \pm 0.00$ & $\mathbf{0 . 1 9} \pm 0.01$ & $\mathbf{0 . 1 9} \pm 0.11$ & $\mathbf{0 . 6 1} \pm 0.18$ \\
$(679)$ & $\mathbf{3}$ & $\mathbf{0 . 9 9} \pm 0.09$ & $\mathbf{0 . 7 0} \pm 0.22$ & $\mathbf{1 . 0 2} \pm 0.29$ & $\mathbf{0 . 7 8} \pm 0.21$ \\
$(736)$ & $\mathbf{4}$ & $\mathbf{0 . 8 7} \pm 0.16$ & $\mathbf{0 . 5 9} \pm 0.22$ & $\mathbf{0 . 8 3} \pm 0.27$ & $\mathbf{0 . 6 0} \pm 0.18$ \\
$(787)$ & $\mathbf{5}$ & $\mathbf{0 . 8 0} \pm 0.16$ & $\mathbf{0 . 5 7} \pm 0.22$ & $\mathbf{1 . 1 0} \pm 0.29$ & $\mathbf{0 . 6 5} \pm 0.19$ \\
$(850)$ & $\mathbf{6}$ & $\mathbf{0 . 8 3} \pm 0.17$ & $\mathbf{0 . 5 6} \pm 0.22$ & $\mathbf{0 . 9 4} \pm 0.23$ & $\mathbf{0 . 6 5} \pm 0.19$
\end{tabular}

n.e.: non estimated due to lack of model convergence

\section{Figures}

Figure 1 : Evolution of the mean weight (g) of European sea bass fed diet M or diet PB over 37 weeks $\left(\mathrm{dpf}=\right.$ days post fertilization). ${ }^{*}$ indicates significant difference $(P<0.1)$.

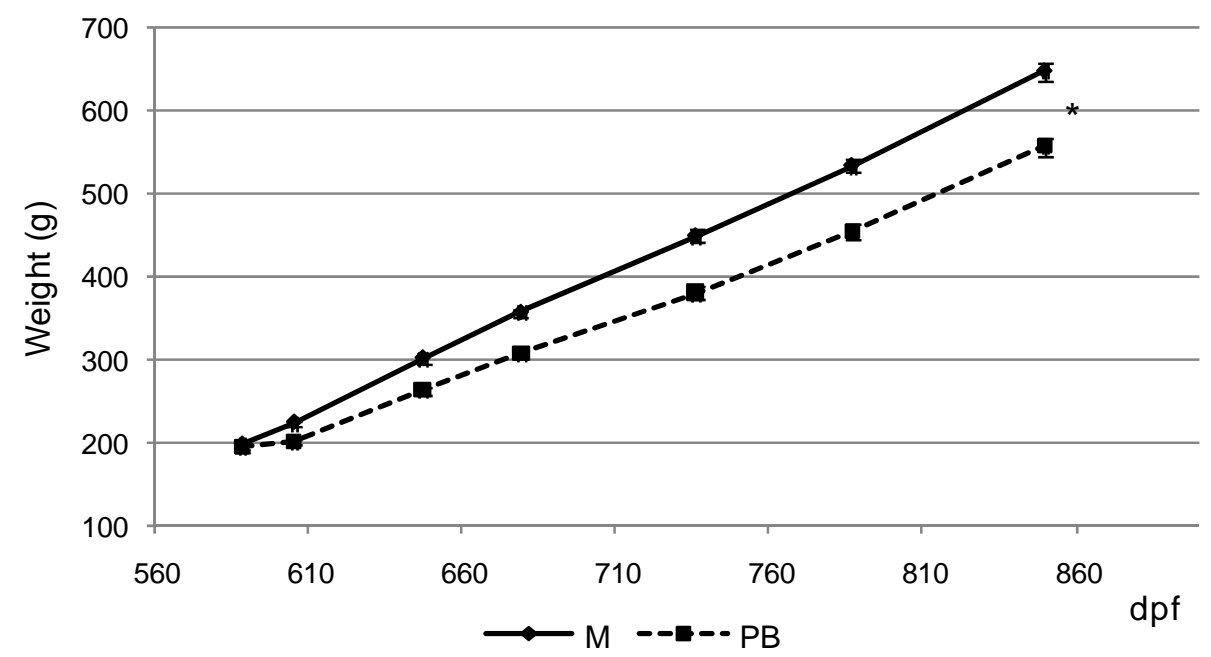

